УДК: 7.034.5: 7.046.3

ББК: 85.143(3), 85.133(3)

DOI: $10.18688 /$ aa2111-06-46

M. D’Attanasio

\title{
The Nativity Chapel in the Church of Santa Maria dei Martiri in Maranola: Court Patronage in Southern Latium
}

In Maranola, a small village in Southern Latium in the archdiocese of Gaeta, there is the Church of Santa Maria dei Martiri ${ }^{1}$; the church is famous in the area for its so called Nativity Chapel (Ill. 126), very important for the strong worship of the villagers and its aesthetic charm.

Despite the fact that the sacellum was realized in modern age, it is very difficult to obtain results that are certain, because there is a big lack of documentation. The restoration works, now in progress, give new important information every day, sometimes modifying the data previously acquired ${ }^{2}$.

The oldest document that mentions the Nativity Chapel is kept in the diocesan historical archive of Gaeta. It is dated June 27, 1647. It reports the quarrel between the archpriest Giovanni Battista Siffredi and don Francesco de Meo, a primicerius of Fondi. The event was testified by Berardina della Rocca who was praying in front of the altar in the Nativity Chapel ${ }^{3}$. Other mentions are present in the inventory (apprezzo) of the fiefs of the Duchy of Traetto (now called Minturno) drawn up in 1690 [20, u.p.] and in the pastoral visits lead by the Bishops of Gaeta in the $17^{\text {th }}$ century.

The most relevant pastoral visits are those of Bishop Carlo Pignatelli made in 1723 and 1728, during which he ordered to clean, repaint, and better arrange the statues of the Nativity scene, as well as to paint the vault and to restore the altar ${ }^{4}$. Later, in September 1775, Bishop Carlo Pergamo ordered to repaint the whole chapel especially the altar steps ${ }^{5}$.

1 It is possible to find the first mention about the church in the inventory of the inheritance of the count of Fondi Onorato II, dated 1491: "Una polisa sub data XII martii, XII indictionis, 1480, per la quale Antonello Aczarito, de Molfecta, confexa havere receputo da Nuczo Andrano, de Lecza, per spendere in Santa Maria de li Martori onze quactro" [32, p. 41]. A few years later, in 1493, the bishop of Gaeta Francesco Patrizi approved the construction of a pilgrim hospital and consecrated in the church of Santa Maria in Maranola three altars dedicated to the Holy Virgin, Saint Sebastian and Saint Blaise [35, p. 83].

2 Unluckily the municipal notarial archives of Gaeta and Maranola are lost. They might have preserved documentations about agreement stipulations and patronage contracts. In 1911, Pasquale Antignano made a report about the Charity Congregation of Maranola whose headquarter was in the Church of Santa Maria dei Martiri. About the church archive he says that it was abandoned and the seals of the $15^{\text {th }}$ century were totally ruined by dust, moths and mice [3, p.5].

3 The document is transcribed in [20]. For this study I could verify the transcription of the useful passage only on the photographic reproduction made by Mastrogiovanni.

4 Archivio storico diocesano di Gaeta (from now on ASDG), C.1.4.2, Visite pastorali, 1722-1772, visita mons. Pignatelli, 1722-1723, u. f.; ASDG, C. 1.4.2; Visite pastorali, 1722-1772, visita pastorale mons. Pignatelli, 1728-1729, f. 109r.

5 ASDG, C. 1.4.2, Visite pastorali, 1773-1798, visita pastorale mons. Pergamo, 1775, u. f. 
The sacellum has a rectangular plan: at about half of its height, it is divided horizontally by a barrel vault which simulates a cave; the two floors are connected by the stairs on the left.

On both sides of the cave, there are two niches with statues inside. The front of the cave, including the stairs on the left and the niches (see Ill. 126), was added to the original cave on an unidentifiable date.

Inside the cave, in the center, there is a low wall and an altar leaned to it.

In the upper part of the sacellum, near the back wall, there is a crenellated wall with two towers at both sides.

Also, this scenic architectural backdrop was probably added at the same time as the front of the chapel was extended.

During the restorations of 2015, the latest painting phase was removed and a decoration came up representing a desert on the sidewall and a decorative pattern similar to damask fabric with large flowers traced by thick red ochre brushstrokes on a yellow base coat.

On the vault, there are the four Evangelists; they rest on clouds, and each one is depicted in half-body with own symbols (Ill. 127) ${ }^{6}$.

Each Evangelist holds a scroll in his hands with the inscribed biblical verses related to the prophecy of the Nativity.

In 2015, the soil on the right of the cave was partially removed, and this made possible an extraordinary discovery: there was a fresco covered by pots and mortar. It represents the Massacre of the Innocents (Ill. 128).

This fresco was covered when the extension of the front of the cave was added. Therefore, it is possible to speculate that the desert landscape in the upper part of the wall was painted after this architectural change, when the Massacre of the Innocents was covered and the background for the statue in the upper part of the vault had to be created.

Another interesting fresco made by the painter of the Evangelist and the Massacre of the Innocents is located on the left wall at the entrance of the cave. The artist depicted St. Bernard of Clairvaux who holds the devil in chains and a young unrecognized female saint (Ill. 129).

The vault of the cave is decorated with little heads of cherubs.

The back wall presented three layers of painting. The most recent one, removed during the conservation work in 2019, represented the town of Bethlehem. Under this layer, there is a fragment of the Nativity scene: it is possible to recognize the head and the bent legs of St. Joseph, the legs of the Virgin and the crib $^{7}$.

The oldest layer is recognizable only for some little fragments that let us speculate that there was the same damask fabric decoration present on the upper part of the chapel.

The prominent role in this chapel decoration belongs to the Nativity scene that counts twenty-seven terracotta statues: sixteen figures and eleven animals.

In the two niches in the front of the cave, there are Prophet Malachi and King David. On the altar inside the cave, there are the main characters: the Holy Virgin, St. Joseph (Ill. 130, 131), Baby Jesus, the Ox and the Donkey. Baby Jesus for sure was replaced; in fact, he is too far from

\footnotetext{
6 The layer of painting removed, datable to the end of the $19^{\text {th }}$ century - beginning of the $20^{\text {th }}$ century, represented four Prophets: Isaiah, Ezekiel, Jeremiah, Elijah, and the Delphic Sibyl.

7 This pictorial phase could be dated at the beginning of the $16^{\text {th }}$ century.
} 
the others statues in terms of style. He seems to look similar to the angel which hangs on the upper vault.

The angel is the annunciating the birth of Christ to two shepherds: one standing with a tortano - typical food of the Neapolitan cuisine - , the other one sitting with a zampogna - a kind of Italian double chantered pipes; all around them, there are sheep, rams, goats, and dogs.

On the left side of the vault, there are the three Magi: Melchior, Caspar, and Balthazar.

Two figures, the Lady with a Child and a shepherd with ricotta, have been severely altered. The Lady, now dressed as a farmer with cheese in her head, before wore a more elegant dress, as some fragments of the original painted layers show (Ill. 132). In addition, the shepherd has been totally reshaped, as we can speculate observing the back of the statues.

The two soldiers have been altered, too. In fact, the heads are way too small for their bodies. Lastly, a small statue of a man, that is very different from the other ones, could be easily identified as an addition.

To this moment, only four statues have been restored, the Holy Virgin, St. Joseph, the Ox and the Donkey, therefore, I will try to base my stylistic analysis exclusively on them, because they are the only ones that reacquired their original form.

The statues of the Virgin and St. Joseph were covered with two pictorial layers on the original surface, which has mostly been recovered.

The pink tunic and the blue cloak of the Virgin hid more precious dresses (Ill. 130).The tunic was silver, as little fragments shown, while the cape was gold. The veil was beige and decorated with a vegetable pattern in silver leaf. A technique similar to the decoration in estofado de oro, typical of Spain and then oftenly used in Naples during the rule of Ferrante of Aragon $[15, \text { p. } 80]^{8}$.

The Holy Virgin wears precious jewels: rings on her fingers and a crow in her head.

To my knowledge, the crowned Virgin is not so common in Nativity scene. A parallel could be found only with the Virgin in the famous Nativity Scene made by Peter and John Alemanno in the Church of San Giovanni a Carbonara in Naples and now preserved in the Museum of the Certosa di San Martino. Currently, the statue has no crown any more, but the contract stipulated in June 30, 1478 says: "figuram Virginis Marie cum corona in capite" [7, p. 56]"; maybe the crown was a singular piece that has been lost.

St. Joseph adores the Baby Jesus (Ill. 131). His cape is gold, while the tunic is green with gold collar and cuff.

Stylistically all the statues have a solid volume made with wide round planes, the dresses have soft creases. The modeler paid a lot of attention to physiognomic characterization and to naturalistic details: see as example the veins on the hand of St Joseph or the grotesque expression on the face of the piper.

To my knowledge, it is impossible to find other statues that were made by the artist who created the Nativity scene of Maranola. The most important stylistic affinities could be found in the Neapolitan sculpture made between the $15^{\text {th }}$ and $16^{\text {th }}$ centuries $[5 ; 1 ; 2 ; 12 ; 14]$, in par-

8 Artists capable of realizing gildings and polychromies on gold have been documented in Naples on the end of the $15^{\text {th }}$ century already. It allows to suppose that there was a deep-rooted local tradition that it has no need of contribution from French or Iberian peninsula [8, p. 151].

9 The notorial act is preserved in the library of the Museo Filangieri in Naples: BMF, II H 7339, c. 47. 
ticular, in the works by Pietro Belverte, the Lombard sculptor who lived in Naples [23; 11, pp. 71-81; 18; 13, pp. 65-67].

Some similarities can be found with the wood sculptures of the Virgin and St. Joseph ${ }^{10}$, which make part of the Nativity scene in the Carafa chapel in St. Dominic, Naples, made between 1507 and 1508 [18, pp.95-96; 19, p. 373].

Another comparison is possible between the Holy Virgin and the lost wooden statue from the Church of San Pietro in Teggiano near Salerno ${ }^{11}$. The two statues are similar in the shape of their chubby faces, and in the flowing folds of their dresses.

The stylistic comparisons let us speculate that the Nativity scene in Maranola was made at the beginning of the $16^{\text {th }}$ century.

Despite the claims of some critics who say that the Nativity scene is related to that in Apulia, because at the beginning of the 1500s in Naples there was no Nativity scene organized in two levels [33, p. 55; 16, pp. 26, 88], I do not agree with that.

First of all, a lot of Nativity scenes made in Naples between the Quattrocento and the 1500s are lost or totally decontextualized ${ }^{12}$; and secondly, it is possible to find another Nativity scene in two levels in the northern Latium, former Abruzzi, that is dated to the very same years of that in Maranola ${ }^{13}$.

\footnotetext{
10 According to Letizia Gaeta this figure could be identified as a Magus [13, p. 67].

11 The style of this statue is not so far from the manner of Giovanni da Nola and Pietro Belverte between 1508 and 1512 [13, pp. 64-65, fig. 33].
}

12 In these years, following a chronological and attributive order, in Naples and surroundings, the following Nativity scenes were made: (i) the one in Sant'Agostino della Zecca sculpted in 1458 by Martino Simone from Zara, (ii) the groups attributable to the association of the brothers Alemanno and the master Francesco Felice - that is the Nativity scene in San Giovanni a Carbonara dated 1478 and (iii) the ones of Santa Maria la Nova, the Annunziata and Sant'Eligio. To Pietro Belverte, it is possible to attribute: (i) the sculpture of Giordano Caetani in the Museo diocesano of Capua that probably was part of a Nativity scene made for one of the chapel of the Cathedral of Capua; (ii) the Nativity scene dated 1507 and commissioned by Ettore Carafa for his sacellum in San Domenico Maggiore in Naples and, (iii) for attribution, the Nativiy scene from Santa Maria della Consolazione in Pozzuoli in which only the Holy Virgin and Saint Joseph are preserved. An emulator of Pietro Belverte was Cristiano Moccia, to him is possible to attribute the Nativity scene documented in 1518 in Santa Maria del Pozzo in Somma Vesuviana in which only the statue of Saint Joseph is preserved. Giovanni da Nola made in 1519 the Nativity scene for the Church of Santa Maria del Parto in Mergellina, on commission by Jacopo Sannazzaro, and maybe at about 1530 that for San Giuseppe Maggiore. Still to Giovanni da Nola it is possible to attribute a dismembered Nativity scene in which remained only the Holy Virgin - preserved in the Museum of Capodimonte - from the De Cicco collection and the mannequin of a shepherd (or Saint Joseph) passed on the Florentine antique market. Lastly, to Domenico Napoletano (called Domenico Impicciati) it is possible to attribute the terracotta of the Virgin Mary adoring baby Jesus - maybe related to the statue of Saint Joseph in San Gregorio Armeno - and the Nativity scene, always in terracotta and unfortunately lost, made in 1532 for Matteo Mastrogiudice [21, p. 6; 9, u. p.; 14, pp. 81, 86, 95; 12, pp. 33-37, 42-46; 18, p. 99; 22].

13 I am talking about the Nativity scene already in San Francesco in L'Aquila (now lost) made by Giacomo da Montereale and most likely finished before 1501 . We do not own any other document that allows us to reconstruct for sure how this Nativity scene was, but in the contract stipulated in 1541 by Giacomo and Raffaele da Montereale for a Nativity scene in the oratory of Sant'Antonio in Calvi in Umbria it is explicitly established that it has to be similar to the Nativity scenes in the churches of San Francesco in Leonessa and San Francesco in L'Aquila and beautiful as that in San Francesco in Rieti. The Nativity scene in Calvi has the Magi procession, so it is possible to argue that the same was present in L'Aquila, a town in periphery of the Kingdom of Naples [6, pp. 78-79]. 
Moreover, I think that it is more probable that Naples, the capital of the kingdom, was the only city capable to impose its artistic supremacy to the provinces. Churches and chapels in Naples were subjected to renovations, so the oldest Nativity scenes must have been lost, and as a consequence, nowadays, we can find the oldest ones only in the churches of the periphery.

Hence, the Nativity scene of Maranola could be the oldest witness in Campania (Formia was part of the Terra di Lavoro) with a Nativity scene in two levels ${ }^{14}$.

Focusing on the painted decoration, it is possible to see an artist whose style is characterized by using more of drawing than color. The contours are made with a dark line, which realizes the details; for example, the wrinkles on the face of St. Luke (Ill. 133). The figures are slim and wear dresses full of creases, the features are tiny and thin. The chromatic range is narrow: the blue of the sky and different shades of red, orange and yellow for the figures; white is only used to make the effect of the light on volumes.

The artist is close to Cristoforo Scacco, a painter who worked in southern Latium and Campania [28; 30, p. 97].

It is possible to draw a comparison between the face of the female saint in Maranola and that of the Holy Virgin in the so-called Cross polyptych made in 1500 for the church of St Anne in Sessa Aurunca [34].

Focusing on the search of the patronage of both kinds of decoration of the chapel, painting and sculpture, it is important to retrace the history of Maranola at the end of the $15^{\text {th }}$ - beginning of the $16^{\text {th }}$ centuries.

At that time, the village was part of the Countship of Fondi and a fief of the Caetani family. More precisely, in 1491, when the count of Fondi Onorato II Caetani died, the fief of Maranola was inherited by his young wife Caterina Pignatelli, who maintained the lordship till her death in 1513, despite that the Colonna family conquered the whole Countship of Fondi few years after the death of Onorato $\mathrm{II}^{15}$.

So, it is very much likely that the artistic patronage is connected to her, as some facts seem to demonstrate.

First of all, the pastoral visits never mention the giuspatronato - the right of patronage of the chapel, so it is possible to interpret this silence as leading back to the local feudal lord (or lady in this case $)^{16}$.

14 Another bond between the Nativity scene in Maranola and those in Naples is the presence of the figure of the shepherd with tortano, documented in the Nativity scene commissioned by Ettore Carafa [10, pp. 585-589] and realized by Giovanni da Nola, or most likely his workshop, for the church of Santa Maria del Parto in Mergellina.

15 In the royal approval to the testamentary disposition of the count Onorato II dated January 15, 1489 it is specified: "[...] Item dictus dominus comes testator recognoscens obsequiosa et grata servitia [...] sibi per excellentem eius coniugem Catherinam Pignatellam de Neapoli, comitissam Fundorum, præstita et impensa, dictæ dominæ Chaterinæ legavit et dari voluit et mandavit castrum ipsius testatoris appellatum Maranula [...] pro residentia et habitatione ipsius comitissae, quoad plenum dominium, usumfructum et proprietatem sua vita durante, dum vitam vidualem servaverit et ad secunda vota non transierit [...]" [31, p. 446, document no. 264, 1 August 1490]. The concession made by king Frederik of Naples towards Prospero Colonna of the fief of the Duchy of Traetto and the Countship of Fondi [31, p. 468, document no. 285, 20 May 1497], among them the feud of Maranola, does not rule out the possibility that Caterina Pignatelli, by rule of a bequest approved by the king, continued to rule Maranola until her death. On the life of Caterina Pignatelli see [4, pp. 156-161].

16 I am grateful to Giovanni Pesiri for sharing with me this hypothesis. 
Another unusual detail is the crown on the head of the Virgin in the Nativity scene. Maybe this is a crypto-portrait of the noble countess Pignatelli; in fact, in other Nativity scenes made in Naples in these years, there were patrons portrayed as figures of the Nativity ${ }^{17}$.

The Caetani family, to which Caterina was related, used to patronize Nativity scenes for their chapels; it is possible to mention the Nativity scene commissioned by Giordano Caetani $[11, \text { p. } 81]^{18}$, brother of Onorato II and the Bishop of Capua, for the Cathedral, and that ordered by Onorato for the Church of St. Dominic in Fondi ${ }^{19}$.

Caterina Pignatelli, commissioning a sculpted Nativity scene as many noble Neapolitans families had done, wanted to imitate her husband, who hired the best artists present in Southern Latium and Naples ${ }^{20}$.

It is not a chance that both Cristoforo Scacco and Pietro Belverte were active for Onorato $\mathrm{II}^{21}$.

With this patronage, Caterina wanted to underline her power over the feud of Maranola.

\section{References}

1. Abbate F. La scultura napoletana del Cinquecento. Roma, Donzelli Editore Publ., 1992. 285 p. (in Italian).

2. Abbate F. Pittura e Scultura del rinascimento. Storia del Mezzogiorno, vol.11, no. 4, Aspetti e problemi del Medioevo e dellétà moderna. Napoli, Edizioni del Sole Publ., 1993, pp.441-489 (in Italian).

3. Antignano P. Deplorevoli condizioni amministrative e finanziarie della Congrega di Carità di Maranola. Castellammare di Stabia, De Meo e figlia Publ., 1911. 20 p. (in Italian).

4. Ascher Y. Politics and Commemoration in Renaissance Naples: The Case of Caterina Pignatelli. Zeitschrift für Kunstgeschichte, 2006, vol. 69, pp. 145-168.

5. Bologna F.; Causa R. (eds.). Sculture lignee nella Campania: Catalogue of the Exhibition, Napoli, Palazzo reale, 1950. Napoli, Stabilimento Tipografico Montanino Publ., 1950. 217 p. (in Italian).

6. Cassio G. Simulacri di terra e colore del Rinascimento tra l'alta valle del Velino, la Sabina e Umbria meridionale. Ai piedi della Laga. Per uno sguardo d'insieme sul patrimonio culturale ferito dal sisma nel Lazio. Milano, Electa Publ., 2019, pp. 68-85 (in Italian).

17 For example it has been supposed a portrait of Ettore Carafa in the character of Saint Joseph in the Nativity scene made by Pietro Belverte for the church of Saint Dominic [13, p. 68; 19, p. 373], or the bishop recognizable as Giordano di Capua, for the lost Nativity scene made for the Cathedral of Capua [14, p. 81]. Last but not least in the contract signed by Domenico Napolitano October 2, 1532 it is established that it has to be added to the other figures of the Nativity scene the portrait of the patron Matteo Mastrogiudice [12, p. 46].

18 On the life of Giordano Caetani, bishop of Capua from 1447 to 1496, see [27].

19 The statues are documented in an anonymous report dated to the beginning of the $17^{\text {th }}$ century included in the miscellaneous manuscript De Familia Caietana; the author could see the nativity scene yet in the church and described it as follow: "[...] vi è un presepio fatto da quel signore $<$ Onorato II $>$ di tanta bellezza che forsi non ha paro nel regno di Napoli et hoggi si tiene in gran veneratione" [25, pp. 103-104].

20 On the patronage of Onorato II Caetani in Fondi and Minturno see [26].

21 Pietro Belverte likely made for Onorato II the wooden door of the portal in the atrium of the Santa Casa dell'Annunziata in Naples [18, pp. 85-95]. The works commissioned by Onorato II to Cristoforo Scacco for Fondi are the following: a panel painting for the major altar in the church of Santa Maria in Piazza (lost), the painting on the lunette in the church of Saint Dominic depicting the Holy Mary between Saint Dominic and Saint Peter Martyr and the count Onorato II (lost), a panel painting for the church in San Francesco representing the Holy Virgin and Child between Saint Francis and Antony (lost), the panel painting with the Holy Lady, Saint Jerome (?) and the archbishop Giordano Caetani (lost?), last, the triptych with Annunciation and the saint Honoratus, Maurus and the Last Supper, previously on the church of the Annunziata now in the church of Saint Peter [24, pp. 80-92; 25, pp. 102-107; 29; 30]. 
7. Catalano M.I. Lume dell'oro nel presepe aragonese. Scultura in legno a Napoli e in Campania fra Medioevo ed età moderna: Proceedings of the Conference, Napoli, Università degli Studi Suor Orsola Benincasa, Soprintendenza Archivistica per la Campania, 4-5 novembre 2011. Napoli, Artstudiopaparo Publ., 2014, pp. 55-65 (in Italian).

8. Cerasuolo A. Estofado e policromie: osservazioni sulla tecnica attraverso la testimonianza di Francesco Pacheco. Per una storia dei sistemi costruttivi e decorativi dal Medioevo al XIX secolo. Bollettino d'arte, 2011, pp. 147-160 (in Italian).

9. Figure presepiali napoletane dal sec. XIV al sec. XVIII: Catalogue of the Exhibition, Napoli, Palazzo Reale, ottobre 1970-gennaio 1971. Napoli, Azienda autonoma di cura soggiorno e turismo Publ., 1970. 106 p. (in Italian).

10. Filangieri G. Documenti per la storia, le arti e le industrie delle province napoletane, vol.3, Napoli, Tip. dell'Accademia Reale delle Scienze Publ., 1885. 680 p. (in Italian).

11. Gaeta L. Sulla formazione di Giovanni da Nola e altre questioni di scultura lignea di primo ‘500. Dialoghi di storia dellarte, 1995, vol. 1, pp. 70-103 (in Italian).

12. Gaeta L. Una proposta per la fase giovanile di Domenico Napolitano e qualche notizia intorno a pittori e scultori del primo Cinquecento a Napoli. Kronos, 2002, vol. 4, pp. 33-48 (in Italian).

13. Gaeta L. Intorno a Pietro Belverte e Giovanni da Nola tra recuperi, restauri e dispersioni. Interventi sulla "questione meridionale". Roma, Donzelli Publ., 2005, pp. 63-69 (in Italian).

14. Gaeta L. Il vero (?) Giovanni Marigliano giovane (Detto Giovanni da Nola). La scultura meridionale in età moderna nei suoi rapporti con la circolazione mediterranea: Proceedings of the International Conference, Lecce, 9-11 giugno 2004, vol. I. Galatina, Congedo Publ., 2007, pp. 195-215 (in Italian).

15. Gaeta L. Sculture in legno a Napoli lungo le rotte mediterranee della pittura. Da Alfonso a Ferrante d'Aragona. Kronos, 2011, vol. 14, pp. 63-96 (in Italian).

16. Gelao C. Il presepe artistico pugliese. Il presepe Pugliese arte e folklore. Bari, Mario Adda editore Publ., 2000, pp.9-92 (in Italian).

17. Liguori G. Il presepe. Note di storia e di arte. Torre del Greco, Palomba\&Mazza Publ., 1927. 75 p. (in Italian).

18. Maietta I. Scultori lombardi a Napoli tra Quattrocento e Cinquecento: aggiunte a Pietro Belverte. Scultori e intagliatori del legno in Lombardia nel Rinascimento: Proceedings of the Conference, Milano, Palazzo di Brera, Istituto Lombardo, Accademia di Scienze e Lettere, 8 maggio 2000. Milano, Electa Publ., 2002, pp. 84-103 (in Italian).

19. Maietta I. 5.23 Pietro Belverte, Madonna e San Giuseppe. Rinascimento visto da Sud. Matera, l'Italia meridionale e il Mediterraneo tra '400 e '500: Catalogue of the Exhibition, Matera, Palazzo Lanfranchi, 19 agosto-15 settembre 2019. Napoli, Arte’m Publ., 2019. p. 373 (in Italian).

20. Mastrogiovanni G. Il Presepio: i documenti. Maranola, il paese del presepe. Formia, Graficar Publ., 2014. (in Italian).

21. Molajoli B. (ed.). La scultura nel presepe napoletano del Settecento: Catalogue of the Exhibition, Napoli, 1950. Napoli, Francesco Giannini \& Figli Publ., 1950. 21 p. (in Italian).

22. Naldi R. Giovanni Marigliano detto Giovanni da Nola, Figura virile in atto di adorare (San Giuseppe o Un pastore). Vetera et nova: Catalogue. Firenze, Edizioni Polistampa Publ., 2005, pp. 86-93 (in Italian).

23. Pesenti F. R. Belverte Pietro. Dizionario Biografico degli Italiani, vol. 8. Roma, Istituto della Enciclopedia Italiana Publ., 1966, pp. 86-87 (in Italian).

24. Pesiri G. Un taccuino di viaggio dell'abate Costantino Gaetani (1603). Appunti su Pignataro Interamna, Ausonia, Fondi, Maenza e Velletri. Le scritture della storia. Studi offerti dalla Scuola Nazionale di studi medievali a Massimo Miglio. Roma, ISIME Publ., 2012, pp.51-110 (in Italian).

25. Pesiri G. Caetani, arte e artisti nel Quattrocento in Terra di Lavoro: scavi documentali su Antoniazzo Romano e Cristoforo Scacco. Fondi e la committenza Caetani nel Rinascimento: Proceeedings of the Conference, Fondi, Palazzo Caetani, 24 maggio 2012. Roma, De Luca Editori d'Arte Publ., 2014, pp. 99-110 (in Italian).

26. Pesiri G. Aspetti del mecenatismo dei Caetani: il pittore Cristoforo Scacco e le ultime committenze artistiche di Onorato II a Fondi e a Minturno (1487-1491). Due convegni veliterni: Giorgio Falco tra Roma e Torino, Velletri, 12 ottobre 2016; Velletri e la Marittima al tempo del giubileo, Velletri, 10 novembre 2016. Tivoli, Edizioni Tored Publ., 2017, pp. 147-196 (in Italian).

27. Pesiri G. Giordano Caetani arcivescovo letterato umanista (sec. XV). Annali del Lazio Meridionale, 2019, vol. 19, no. 1, pp. 5-33 (in Italian). 
28. Petrocchi S. 12.6 Ambito di Cristoforo Scacco, Santa Caterina e Santo Monaco; Madonna ed Evangelisti. La pittura del Quattorcento nei Feudi Caetani. Roma, Edizioni di storia e letteratura Publ., 2013, p. 493 (in Italian).

29. Petrocchi S. Cristoforo Scacco, gli ultimi splendori della contea Caetani di Fondi. La pittura del Quattrocento nei feudi Caetani. Roma, Edizioni di Storia e Letteratura Publ., 2013, pp.461-502 (in Italian).

30. Petrocchi S. Cristoforo Scacco alla corte Caetani di Fondi. Fondi e la committenza Caetani nel Rinascimento: Proceeedings of the Conference, Fondi, Palazzo Caetani, 24 maggio 2012. Roma, De Luca Editori d'Arte Publ., 2014, pp. 85-98 (in Italian).

31. Pollastri S. Les Gaetani de Fondi. Recueil d'actes (1174-1623). Roma, L'Erma di Bretschneider Publ., 1998. 537 p. (in French).

32. Pollastri S. (ed.). Inventarium Honorati Gaietani. L'inventario dei beni di Onorato II Gaetani d'Aragona (1491-1493). Roma, L'Erma di Bretschneider Publ., 2006. 332 p. (in Latin and Italian).

33. Ruggiero M. Il presepe italiano. Storia di un costume. Torino, Il capitello Publ., 1988. 173 p. (in Italian).

34. Salvatore D. 5.14 Cristoforo Scacco, Adorazione della Croce, con Costantino e Sant'Elena e un cavatore. Rinascimento visto da Sud. Matera, l'Italia meridionale e il Mediterraneo tra '400 e '500: Catalogue of the Exhibition, Matera, Palazzo Lanfranchi, 19 agosto-15 settembre 2019. Napoli, Arte’m Publ., 2019, p. 362 (in Italian).

35. Tommasino L; Tommasino M. Chiesa di Santa Maria ad Martires, Maranola. Le architetture religiose nel Golfo di Gaeta. Scauri, Caliman studio Publ., 2006, pp. 82-85 (in Italian).

Title. The Nativity Chapel in the Church of Santa Maria dei Martiri in Maranola. Court Patronage in Southern Latium

Author. D'Attanasio, Marco - Ph. D. Superintendence of Archeology, Fine Arts and Landscape for the provinces of Frosinone and Latina, Via Pompeo Magno 2, 00192 Rome (RM) Italy. marco.dattanasio@gmail. com ORCID: 0000-0003-1702-8328

Abstract. In Maranola there is the Church of Santa Maria dei Martiri, famous for the Nativity Chapel. Despite the fact that the sacellum was realized in modern age, it is very difficult to obtain sure information, because of the lack of documentation. The sacellum has a rectangular plan, at about half of its height it is divided horizontally by a barrel vault that simulates a cave; the two floors are connected by stairs on the left. In the cross vault of the upper level there are painted the four Evangelists with their symbols. In the lower level of the chapel are recognizable two pictorial layers in which the fragmentary Nativity is visible. It is possible to date these paintings to the beginning of the $16^{\text {th }}$ century because they are stylistically close to the manner of Cristoforo Scacco, a painter well known in Southern Latium at that time. The decoration of the chapel is completed by a Nativity scene with twenty-seven terracotta sculptures. In the lower floor of the chapel there are: Baby Jesus, The Holy Virgin, St. Joseph, the ox and the donkey and two Prophets: king David and Malachi. In the upper floor there are the Three Magi, the Annunciating Angel, two shepherds and many animals. The crèche is stylistically close to the Neapolitan sculpture of the end of the $15^{\text {th }}$ - beginning of the $16^{\text {th }}$ century. Even if there are no documents, it seems possible to connect the patronage of the Nativity Chapel to Caterina Pignatelli, the wife of the count of Fondi Onorato II Caetani. With this patronage, she wanted to underline her power over the feud of Maranola.

Keywords: Latium, Maranola, Nativity scene, painting, terracotta, sculpture, Cristoforo Scacco, Caterina Pignatelli, Fondi, Neapolitan Kingdom

Название статьи. Капелла Рождества церкви Санта Мария деи Мартири в Мараноле. Придворный патронаж в Южном Лации

Сведения об авторе. Марко д’Аттаназио - Ph. D. Управления археологии, изобразительного искусства и ландшафта в провинциях Фрозиноне и Латина. Виа Помпео Магно 2, 00192 Рим, Италия. marco. dattanasio@gmail.com ORCID: 0000-0003-1702-8328

Аннотация. Церковь Санта Мария деи Мартини в Мараноле примечательна входящей в ее ансамбль капеллой Рождества Христова. Несмотря на то, что пространство было возведено в Новое время, сохранилось мало сведений относительно его постройки. Капелла, прямоугольная в плане, на половине высоты разделена бочкообразным сводом, имитирующим пещеру; ярусы соединены лестницей слева. Крестовый свод верхнего яруса украшен живописью с изображением четырех евангелистов и их символов. На нижнем ярусе можно различить два живописных слоя с изображением сцены Рождества. Росписи датированы началом XVI в. на основе их стилистического сходства с живописью Кристофоро Скакко, художника, хорошо известного в Южном Лации в этот период. Декорация капеллы дополнена 
рождественским вертепом с двадцатью семью терракотовыми скульптурами. В «пещере» на нижнем ярусе расположены скульптуры Младенца, Богоматери и Святого Иосифа, фигуры вола и осла, а также двух пророков - царя Давида и Малахии. На верхнем ярусе находятся скульптуры трёх Волхвов, Ангела-благовестника, двух пастухов и множества животных. Ясли стилистически близки к неаполитанской скульптуре конца XV - начала XVI вв. Несмотря на отсутствие подтверждающих документов, представляется возможным связать строительство капеллы Рождества с покровительством Катерины Пиньятелли, жены графа Фонди Онорато II Каэтани, которая хотела подчеркнуть свою власть над феодами Маранолы.

Ключевые слова: Лаций, Маранола, рождественский вертеп, живопись, терракота, скульптура, Кристофоро Сакко, Катерина Пиньятелли, Фонди, Неаполитанское королевство 


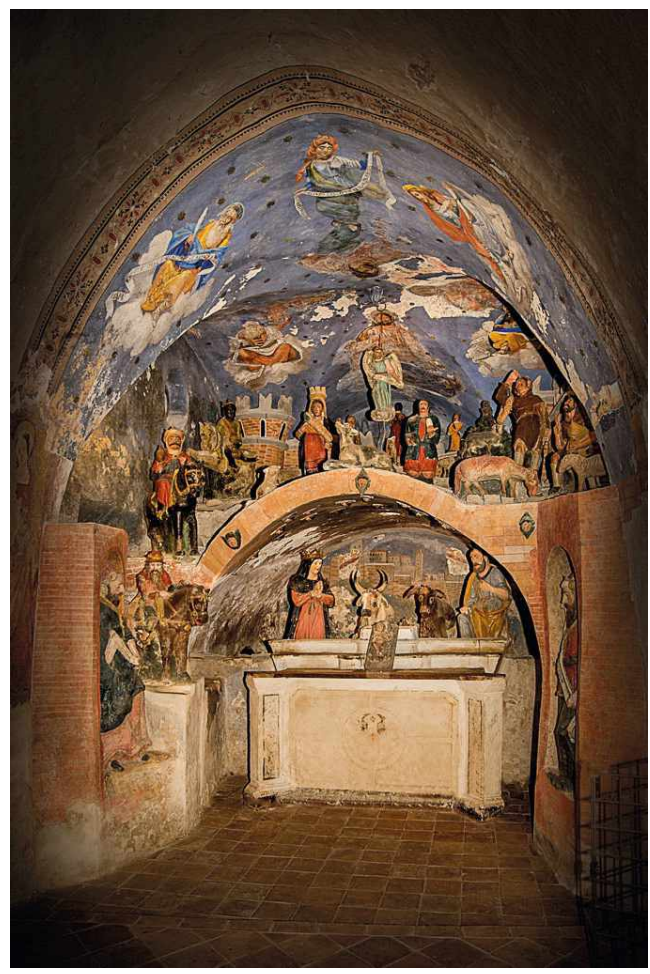

Ill. 126. The Nativity Chapel, Santa Maria dei Martiri,

Maranola. Photo by M. D’Attanasio

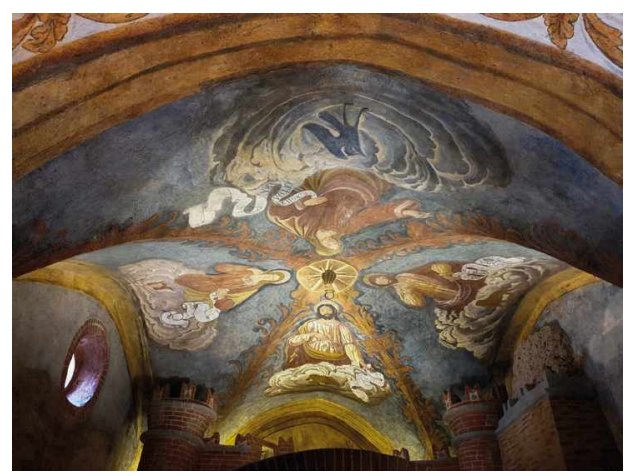

Ill. 127. The four Evangelists. Santa Maria dei Martiri, Maranola. Photo by M. D’Attanasio
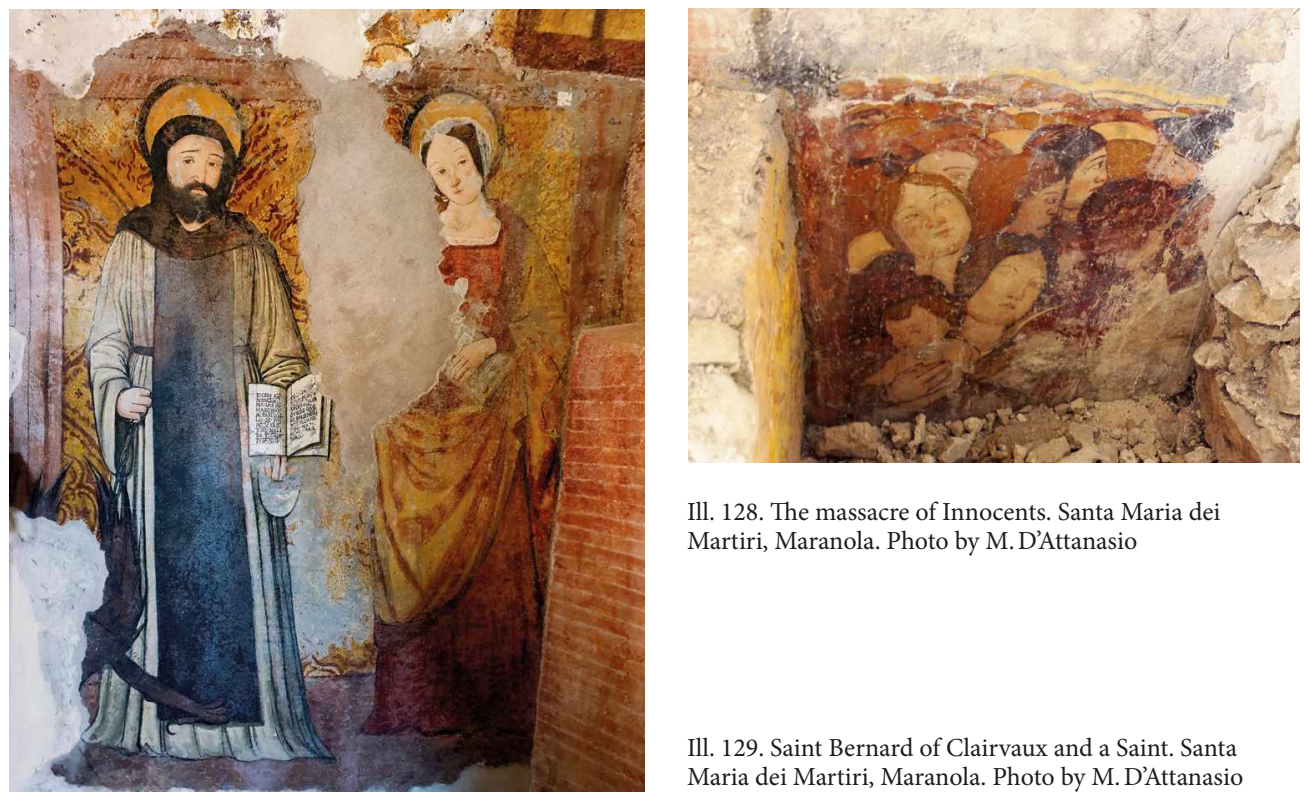

Ill. 128. The massacre of Innocents. Santa Maria dei Martiri, Maranola. Photo by M. D’Attanasio

Ill. 129. Saint Bernard of Clairvaux and a Saint. Santa Maria dei Martiri, Maranola. Photo by M. D’Attanasio 


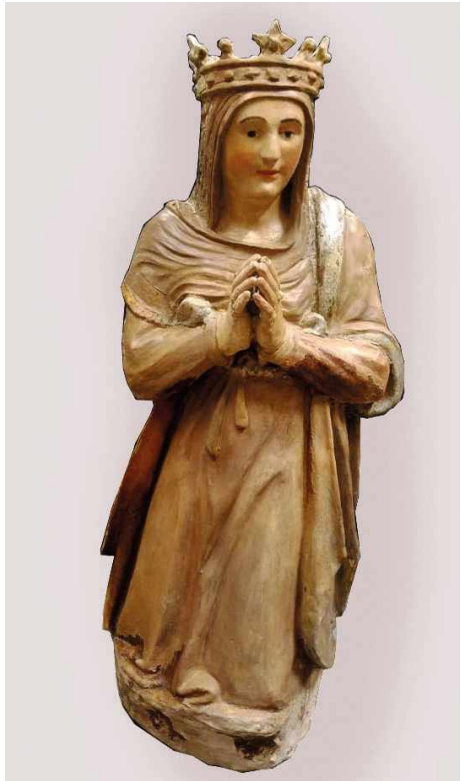

Ill. 130. The Holy Virgin. Santa Maria dei Martiri, Maranola. Photo by M. D’Attanasio

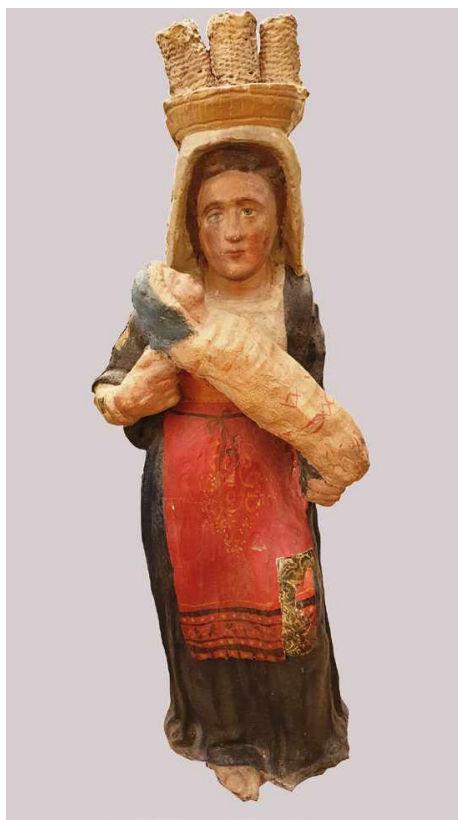

Ill. 132. Lady with a baby. Santa Maria dei Martiri, Maranola. Photo by M. D’Attanasio

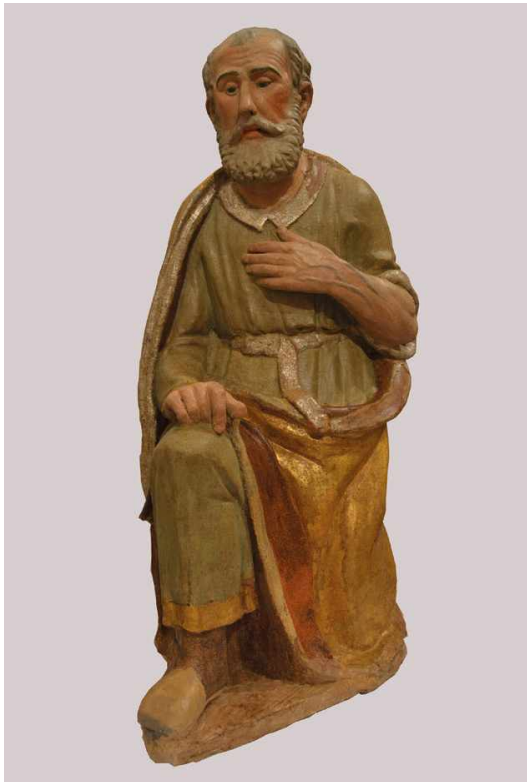

Ill. 131. Saint Joseph. Santa Maria dei Martiri, Maranola. Photo by M. D’Attanasio

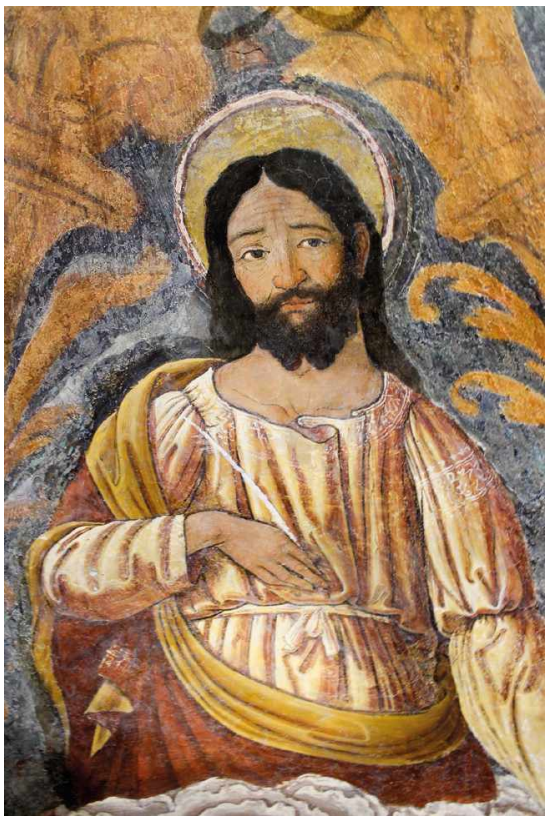

Ill. 133. Saint Luke Evangelist. Santa Maria dei Martiri, Maranola. Photo by M. D'Attanasio 